\title{
Biochemical Evaluation of Garden-Strawberry Berries When Using Foliar Top-Dressing
}

\section{Natalia Mistratova, Elena Savinich, and Anna Samarokova}

Krasnoyarsk State Agrarian University, 90 Mira Av., Krasnoyarsk, 660049 Russia

ORCID:

Natalia Mistratova: http://orcid.org/0000-0003-0973-6113

\section{Abstract}

This study examined the use of foliar treatment with solutions of macroand microelements when growing garden strawberries of the varieties Elista, Pervoklassnitsa, Zephyr, and Solnechnaya Polyanka in the conditions of the Krasnoyarsk forest. The agrochemical background of the soil when planting garden strawberry bushes in the open ground indicated its high fertility in terms of a set of indicators. At the same time, there was a shortage of micronutrient elements in the soil at the experimental site: $\mathrm{Cd}(0.2 \mathrm{mg} / \mathrm{kg}), \mathrm{Cu}(0.5 \mathrm{mg} / \mathrm{kg}), \mathrm{Zn}(1.3 \mathrm{mg} / \mathrm{kg}), \mathrm{Co}(0.6 \mathrm{mg} / \mathrm{kg})$ and $\mathrm{Cr}$ $(0.3 \mathrm{mg} / \mathrm{kg})$. Availability of manganese $(65.4 \mathrm{mg} / \mathrm{kg})$ and lead $(2.0 \mathrm{mg} / \mathrm{kg})$ was average.

Corresponding Author:

Natalia Mistratova

mistratova@mail.ru

Published: 5 April 2021

Publishing services provided by Knowledge E

(c) Natalia Mistratova et al. This article is distributed under the terms of the Creative Commons Attribution License, which permits unrestricted use and redistribution provided that the original author and source are credited.

Selection and Peer-review under the responsibility of the DonAgro Conference Committee. The Elista variety was distinguished in the control version of the experiment in the accumulation of copper in the berries $(0.9 \mathrm{mg} / \mathrm{kg})$. After foliar treatments with $\mathrm{Cu} 1 \%+8$ microelements, the highest $\mathrm{Cu}$ content was observed in the berries of the Solnechnaya Polyanka $(1.1 \mathrm{mg} / \mathrm{kg})$ and Pervoklassnitsa $(1.0 \mathrm{mg} / \mathrm{kg})$ varieties. The Zephyr variety had the lowest copper content in its berries: $0.4 \mathrm{mg} / \mathrm{kg}$. The control variant of the Zephyr variety was distinguished in its iron content $(4.6 \mathrm{~m} / \mathrm{kg})$. After foliar treatments with $\mathrm{Fe} 2 \%+8$ micronutrient elements, the maximum amount of iron in the berries was recorded in the Solnechnaya Polyanka variety: $4.4 \mathrm{mg} / \mathrm{kg}$. The Elista and Zephyr varieties had a rich biochemical composition without treatment with micronutrient elements. The Pervoklassnitsa and Solnechnaya Polyanka varieties were responsive to foliar feeding with micronutrient elements.

Keywords: Strawberries, non-root top-dressing, biochemical composition of berries

\section{Introduction}

Strawberries are a widespread berry crop among the population of the Krasnoyarsk Territory. Despite its low winter hardiness in a sharply continental climate, it is valued for its yield, large-fruit, high taste qualities of fresh berries and their processed products [1].

T.G. Prichko, M.G. Germanov and T.L. Smelyk [2] note that, consuming the usual diet for modern humans, the body loses $40-60 \%$ of the required amount of vitamins and biologically significant macro- and micronutrients. Garden strawberry berries are the 
richest source of an antioxidant complex, mainly $\mathrm{C}$ and $\mathrm{P}$ vitamins. The well-known hematogenous (the creation of blood) effect of strawberries is associated with the presence of vitamins C, B9, and iron [3].

Currently, a healthy lifestyle is being actively promoted among the population of Russia, while interest in biologically active substances of natural origin obtained from plant products is increasing [4]. In this regard, obtaining high quality strawberries with a rich biochemical composition of the fruits is one of the tasks of the horticulture industry [5-7].

Agrricultural practices for optimizing of mineral nutrition in modern gardening is given an important role, while increasing the productivity of agricultural plants, including fruit and berry, as well as their environmental sustainability [8; 9, 10]. Nutrients can enter plants not only through the roots, but also through the stems and leaves. Therefore, one of the most promising methods of using fertilizers is non - root processing. Mechanisms of non-root nutrition and their role in determining the quality of fruits have not been studied enough. Growing conditions, varieties, agricultural techniques, as well as applied fertilizers can affect the accumulation of micronutrient elements in fruits and thus have a corrective effect on their nutritional and vitamin value [11,12].

The aim of the research is to study the effect of foliar dressing on the biochemical composition of strawberries in the conditions of the Krasnoyarsk forest-steppe.

\section{Methods and Equipment}

The research was conducted in 2018-2020. The planting material of strawberry varieties for the experiment was purchased at the State fruit and berry variety testing site in Shushenskoye (Krasnoyarsk territory) and complied with the standart [13]. Research objects - garden strawberry varieties Elista, Pervoklassnitsa, Zephyr, Solnechnaya Polyanka. Landing pattern $70 \times 30 \mathrm{~cm}$, single-row, narrow-band. The area of the experimental plot is $44.1 \mathrm{~m} 2$. Repeatability is 3 times, and placement is systematic. The experimental options included exogenous treatment (spraying) with water solutions of nutrient elements in chelate form (manufacturer LLC RIC Bashlnkom, Ufa): 1) control (spraying with water); 2) N-1.6\% + 8 minor nutrient element (Fe-0.4\%, Cu-0.12\%, B0.028\%, Mn-0.36\%, Zn-0.09\%, Mg-0.05\%, Mo-0.08\%, Co-0.016\%); 3) Cu 1\% + 7 minor nutrient element (Mn-0.018\%, Fe-0.02\%, Mo-0.004\%, Co-0.00018\%, B-0.0014\%, Zn0.0045\%, Mg-0. 0025\%); 4) Fe 2\% 7 minor nutrient elements (Mn-0.018\%, Cu-0.006\%, Co-0.0008\%, B-0.0014\%, Mo-0.004\%, Zn-0.0045\%, Mg-0.0025\%). 
Laboratory analysis of soil samples from the experimental site and analysis of berries were carried out at the Research Center of the Krasnoyarsk State Agrarian University. The content of trace elements in berries was determined by the atomic adsorption method on the spectrophotometer "PinAAcle 900T." Mathematical processing of the research results was carried out by the method of analysis of variance [14] using the MS Excel computer program.

\section{Results and Discussion}

The soil of the experimental site is black soil, characterized by a high humus content of $8.3 \%$ and a neutral reaction of the soil medium ( $\mathrm{pHwater} 7.5$ ). The agrochemical background of the soil when planting garden strawberry bushes in the open ground indicates its high fertility in terms of a set of indicators and met the requirements for the cultivation of this crop At the same time, there is a shortage of micronutrient elements in the soil at the experimental site: low content-Cd (0.2), $\mathrm{Cu}(0.5 \mathrm{mg} / \mathrm{kg}), \mathrm{Zn}(1.3 \mathrm{mg} / \mathrm{kg})$, Co $(0.6 \mathrm{mg} / \mathrm{kg}), \operatorname{Cr}(0.3 \mathrm{mg} / \mathrm{kg})$. Availability of manganese $(65.4 \mathrm{mg} / \mathrm{kg})$ and lead $(2.0$ $\mathrm{mg} / \mathrm{kg}$ ) is average.

TABLE 1: The content of macro- and micronutrients in the experimental plot soil, 2018

Index
Nitrate-nitrogen
Ammonium nitrate
Potassium according to Chirikov
Phosphorus according to Chirikov
Lead
Cadmium
Copper
Zinc
Nickel
Cobalt
Chromium
Manganese

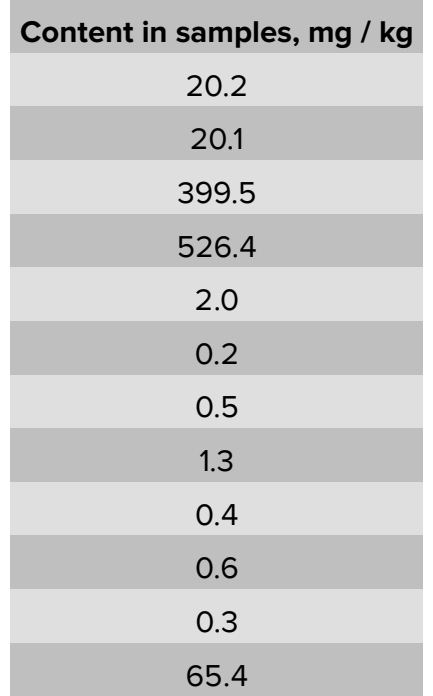

\begin{tabular}{|c|}
\hline Degree of security \\
Very high \\
Very high \\
Very high \\
Very high \\
Average \\
Low \\
Low \\
Low \\
Low \\
Low \\
Low \\
Average
\end{tabular}

Since the experiment studied the effect of foliar dressing with compositions of micronutrient elements with an increased content of copper (III variant) and iron (IV variant), taking into account the accumulation of these trace elements in berries, the following results were obtained: according to the accumulation of copper, the Elista variety $(0.9 \mathrm{mg} / \mathrm{kg})$ on the control variant of the experiment (water treatment). After non-root treatments of $\mathrm{Cu} 1 \%+8$ trace elements, the highest copper content was noted 
in berries of the varieties Solnechnaya Polyanka $(1.1 \mathrm{mg} / \mathrm{kg})$ and Pervoklassnitsa $(1.0$ $\mathrm{mg} / \mathrm{kg}$. The Zephyr variety showed the lowest Cu content in berries - $0.4 \mathrm{mg} / \mathrm{kg}$ (Figure 1).

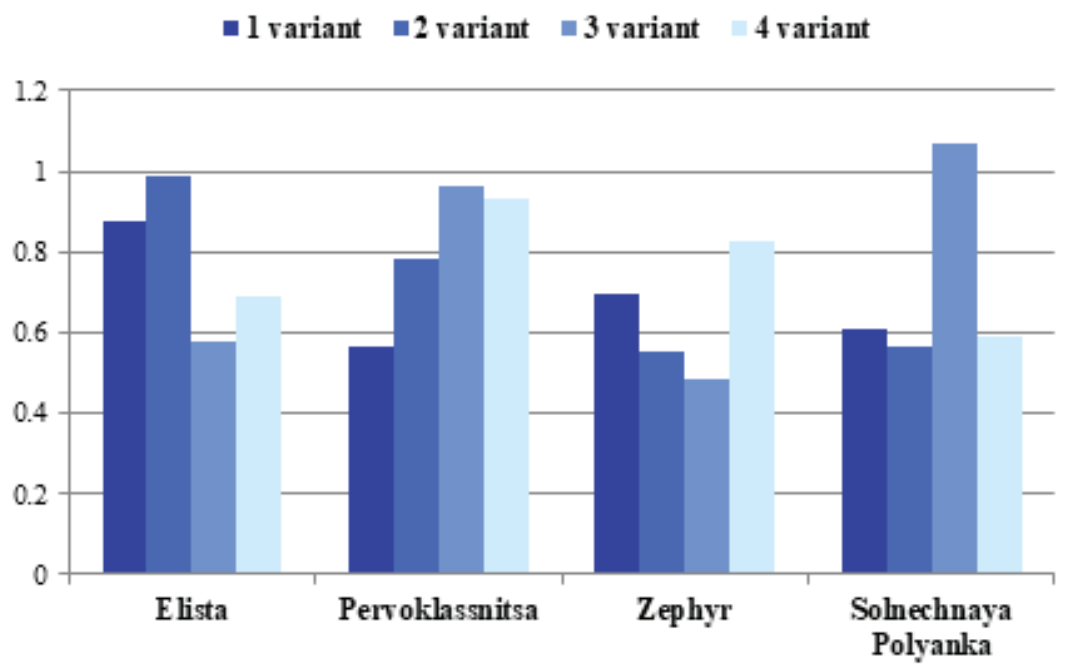

Figure 1: The effect of foliar treatments on the copper content in the berries of garden strawberry by experiment variants, $\mathrm{mg} / \mathrm{kg}, 2019$

According to the iron content in the berries, the Zephyr variety $(4.6 \mathrm{mg} / \mathrm{kg})$ was distinguished in the control variant, after foliar treatments with Fe $2 \%+8$ trace elements, the maximum amount of iron in the berries was recorded in the Solnechnaya Polyanka variety $-4.4 \mathrm{mg} / \mathrm{kg}$. The Elista and Zephyr varieties showed almost equal results, 4.0 $\mathrm{mg} / \mathrm{kg}$ and $3.8 \mathrm{mg} / \mathrm{kg}$, respectively (Figure 2 ).

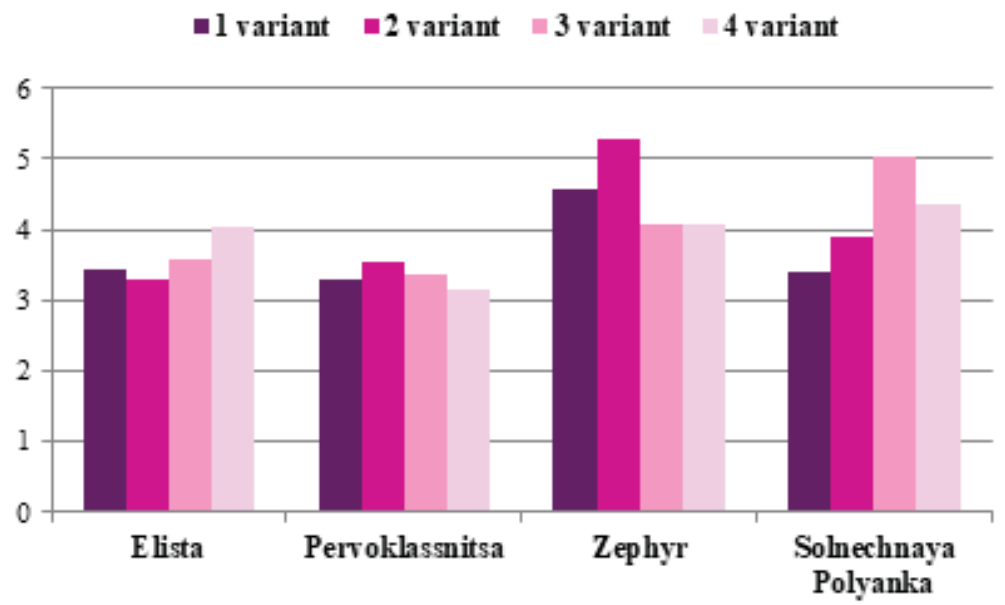

Figure 2: The effect of foliar treatments on the iron content in the berries of garden strawberry byexperiment variants, $\mathrm{mg} / \mathrm{kg}, 2019$ 
Dispersion analysis of data on the accumulation of trace elements in strawberries indicates that there are no statistically significant differences in varieties and variants of experience (Table 02).

TABLE 2: Dispersion analysis of micronutrient accumulation in garden strawberry berries

\begin{tabular}{|c|c|c|c|c|c|c|c|}
\hline Element & $\begin{array}{l}\text { Source of } \\
\text { variation }\end{array}$ & SS & df & MS & $\mathbf{F}$ & $\begin{array}{c}\text { P- } \\
\text { significance }\end{array}$ & F-critical \\
\hline \multirow[t]{2}{*}{$\mathrm{Mn}$} & Variety & 0.003756 & 2 & 0.001878 & 0.648752 & 0.570134 & 6.944272 \\
\hline & $\begin{array}{c}\text { Experience } \\
\text { variant }\end{array}$ & 0.002756 & 2 & 0.001378 & 0.476008 & 0.652463 & 6.944272 \\
\hline \multirow[t]{2}{*}{$\mathrm{Fe}$} & Variety & 0.008089 & 2 & 0.004044 & 0.729459 & 0.536917 & 6.944272 \\
\hline & $\begin{array}{c}\text { Experience } \\
\text { variant }\end{array}$ & 0.018489 & 2 & 0.009244 & 1.667335 & 0.297412 & 6.944272 \\
\hline \multirow[t]{2}{*}{$\mathrm{Cu}$} & Variety & 0.001089 & 2 & 0.000544 & 1.580645 & 0.311988 & 6.944272 \\
\hline & $\begin{array}{c}\text { Experience } \\
\text { variant }\end{array}$ & 0.000689 & 2 & 0.000344 & 1 & 0.444444 & 6.944272 \\
\hline \multirow[t]{2}{*}{$\mathrm{Mg}$} & Variety & 0.005756 & 2 & 0.002878 & 0.087088 & 0.918287 & 6.944272 \\
\hline & $\begin{array}{c}\text { Experience } \\
\text { variant }\end{array}$ & 0.004422 & 2 & 0.002211 & 0.066913 & 0.936301 & 6.944272 \\
\hline \multirow[t]{2}{*}{$\mathrm{Ni}$} & Variety & 0.0002 & 2 & $1 \mathrm{E}-04$ & 0.5 & 0.64 & 6.944272 \\
\hline & $\begin{array}{c}\text { Experience } \\
\text { variant }\end{array}$ & 0.0008 & 2 & 0.0004 & 2 & 0.25 & 6.944272 \\
\hline
\end{tabular}

Berries of the Elista cultivar in the control variant showed the highest content of a number of microelements (Mn, Mg, Ni, Fe, $\mathrm{Cu}$ ). The Zephyr variety also had an excess of $\mathrm{Mg}$ accumulation in the control variant relative to the variants with micronutrient treatment

\section{Conclusion}

Elista and Zephyr were varieties with a rich biochemical composition, without treatment with trace elements. On the other hand, the varieties Pervoklassnitsa and Solnechnaya Polyanka showed responsiveness to foliar feeding with microelements.

\section{Conflict of Interest}

The authors have no conflict of interest to declare. 


\section{References}

[1] Bopp, V. L., Kuzmina, E. M. and Mistratova, N. A. (2020). Horticulture of Siberia. Krasnoyarsk: Krasnoyarsk State Agrarian University.

[2] Prichko, T. G., Germanova, M. G. and Smelik, T. L. (2019). Commercial Qualities and Chemical Composition of Strawberry Berries Selection of FSBSI NCFSCGVWM. Fruit and berry growing in the South of Russia. vol. 58(04), pp. 104-113. Retrieved from http://journalkubansad.ru/pdf/19/04/09.pdf. Date of the application 02.08.2020.

[3] Mistratova, N. A., Savinich, E. A. and Forsel, A. V. (2017). Assessment of Varieties Fragaria Ananassa Duch. On Biochemical and Commodity Indicators of Berries in the Conditions of the Krasnoyarsk Forest-Steppe. Pomiculture and Small Fruits Culture in Russia, vol. 5, pp. 72-76.

[4] Pennington, J. and Fisher, R. (2010). Food Component Profiles for Fruit and Vegetable Subgroups. Journal of Food Composition and Analysis, vol. 23, pp. 411-418.

[5] Yakovenko, V. V. and Lapshin, V. I. (2014). Assessment of Strawberry Varieties by Yield and Quality of Berries. Fruit and berry growing in the South of Russia. vol. 28(04), pp. 1-8. Retrieved from journal.kubansad.ru/pdf/14/04/05.pdf. Date of the application 05.08.2020.

[6] Prichko, T. G., et al. (2016). Influence of Foliar Dressings on the Quality of Strawberries. Fruit and berry growing in the South of Russia. vol. 58(04), pp. 104-113. Retrieved from httpjournal.kubansad.ru160413.pdf. Date of the application 05.08.2020.

[7] Vetrova, O. A. and Roeva, T. A. (2019). The Effect of Mineral Fertilizers on the Biochemical Composition and Quality of Fruits. Modern gardening. vol. 3, pp. 4869. Retrieved from http://journal-vniispk.ru/pdf/2019/3/33.pdf. Date of the application 10.08.2020.

[8] Kondakov, A. K. (2006). Fertilization of Fruit Trees, Berry Fields, Nurseries and Flower Crops. Michurinsk: Michurinsky State Agrarian University.

[9] Popova, V. P., Fomenko, T. G. and Petrov, I. A. (2013). Efficiency of using Fertilizers and New Generation Growth Regulators to Increase Productivity of Apple Trees. Fruit and berry growing in the South of Russia. vol. 19(1), pp. 75-87. Retrieved from http://journalkubansad.ru/pdf/13/01/09.pdf Date of the application 10.08.2020.

[10] Rezvyakova, S. V. and Gurin, A. G. (2020). Technology for the Production of High-Quality Apple Seedlings based on Growth Stimulants and Fertilizers. Fruit and berry growing in the South of Russia. vol. 64(4), pp. 78-88. Retrieved from http://journalkubansad.ru/pdf/20/04/07.pdf. Date of the application 10.08.2020. 
[11] Levkova, M. Y., et al. (2005). About the Possibility of using Medicinal Plants for the Treatment and Prevention of Microelementosis and Pathological Conditions. Micronutrients in Medicine, vol. 6, pp. 3-10.

[12] Voloshin, E. I. (2015). Fertilizer Application Guide for Berry Crops. Krasnoyarsk: Krasnoyarsk State Agrarian University.

[13] State Standart R 53135-2008 Planting Material of Fruit, Berry, Subtropical, NutBearing, Citrus Crops and Tea. Retrieved from: http://docs.cntd.ru/document/ 1200069387. Date of the application 10.08.2020.

[14] Dospekhov, V. A. (1985) Methods of Field Experience. Moscow: Agropromizdat. 